\title{
Reasonable or objective term in criminal proceedings?
}

\author{
Svetlana Valentinovna Medvedeva ${ }^{1 *}$, Aleksey Mikhailovich Popov $^{2}$, Olga Petrovna \\ Kopylova $^{1}$, Elena Vasilyevna Burtseva ${ }^{1}$, and Andrey Vladimirovich Seleznev ${ }^{1}$ \\ ${ }^{1}$ Tambov State Technical University, Department of Criminal Law and Applied Informatics in \\ Jurisprudence, Tambov, Russia \\ ${ }^{2}$ Moscow Academy of the Investigative Committee of the Russian Federation, Department of \\ Criminology, Moscow, Russia
}

\begin{abstract}
The course for the transformation of criminal proceedings held in Russia already bears certain fruit and this is stipulated by the democratic transformations taking place in the country. The prerequisite of the research of a reasonable term of criminal proceedings was the fact that the urgency of the criminal trial is of interest not only for scientists and law-makers but also for the accused, defendants, and victims, whose rights are breached in long-term criminal proceedings. The state shall guarantee the compensation of harm for the delay of terms of criminal proceedings not only to the accused and suspected but also to the victims. For this, it is necessary to use certain criteria that explain what terms should be considered reasonable. When writing the article, the authors used the methods of analysis, synthesis, logical and system approaches. As the study of the problem was performed by the authors from the point of view of the two aspects of its understanding - from the scientific point of view and administration of law, eventually the chosen methods allowed reaching the set objective of the research - to reveal the peculiarities of a reasonable term of criminal proceedings and also to develop suggestions for the improvement of legislation in the field under consideration. The authors believe that the preliminary investigation and the trial should determine the acceptable or objective term of criminal proceedings to deliver a fast, legal, and relevant judgment upholding by this the rights of all participants in the process. Basing upon the issue declared, the authors analyze the concept of a reasonable term in criminal proceedings, how it is implemented in practice, and propose to legislate the concept of the reasonable term in Article 5 of the Russian Federation Code of Criminal Procedure.
\end{abstract}

Keywords: entry terms, broader concept, preferred term

\section{Introduction}

A citizen has the right to the trial of a case by the independent court established by the law during a reasonable term [1].

\footnotetext{
*Corresponding author: sv-medvedeva@mail.ru
} 
The most important guarantee of upholding the rights of the participants in criminal proceedings is a term, but what is it - "reasonable" or "objective"? The case law knows the cases when the accused was in custody for a long time. Therefore, it is important to find an indictment and deliver a judgment for every criminal case in a reasonable term; however, at the same time, this process should not be rushed. In the condition of the pandemic, the Supreme Court of the Russian Federation also paid special attention to the application of the criminal procedure legislation regarding the observance of the procedural terms. That is why the authors decided to study the problem of terms of legal proceedings in this article.

The works by Bykov, Barygina, Kushnerev, Obraztsov, Nikolyuk, and other scientists and experts were dedicated to the problem of terms of criminal proceedings.

The hypothesis of the research is to legislate the concept of "reasonable term" as objective (that is, unprejudiced, free from prejudice and subjective attitude), depending upon the category (simplicity or complexity) of investigation activities and judicial proceedings.

The objective of the research is to study the peculiarities of the reasonable term in criminal proceedings.

\section{Methods}

When writing the article, the authors used the methods of analysis, synthesis, logical and system approaches. The study was performed from the point of view of the two aspects of its understanding - from the scientific point of view and administration of law; therefore, the scientific literature and examples from practice were used as sources.

\section{$3 \quad$ Results}

It was proposed to legislate the concept of the reasonable term in Article 5 of the Russian Federation Code of Criminal Procedure: "A reasonable term is a period of time when the legal proceedings have an objective character without a significant excess of the established terms of criminal proceeding".

\section{Discussion}

The urgency of criminal proceedings was pointed out by Dukhovskoy in 1910 in his book Russian Criminal Proceedings. He mentioned that the main disadvantage of the process was its duration. In the Statute of Criminal Proceedings published in 1910, the terms of preliminary investigation and legal proceedings were specified.

Foreign sources say that in the modern reality that is directed first of all to the nonbreaching of the rights and freedoms of citizens, and the possibilities of access to court were constantly explained by various authorities, the number of claims increased, including those filed for the compensation of harm caused by the illegal or formal actions of preliminary investigation bodies [2].

Until now, the claims based upon the non-observance of the requirement of the "reasonable term" were directed to the duration and not to the brevity of the investigated proceeding [3, p. 29; 4].

Discussing the scope of the right to a hearing within a reasonable time amounts to discussing the scope of Article 6 of the Convention as such. This subject has given rise to extensive and complex case-law that goes well beyond the limits of this study. It is nevertheless important to provide some idea of where the reasonable-time requirement applies, especially as the wording of Article 6 and the case-law arising out of it are far from 
straightforward. In the problem under consideration, the authors shall address the opinion of scientists-processualists [5, p. 7].

Thus, Professor Bykov says that for criminal proceedings, terms are important, but they shall not be given the value of principles [6].

Barygina has an opposite point of view, believing that the elimination of terms of criminal proceedings shall be legislated in the law of code of criminal procedure as a provision that should be striven, that is, as a principle [7].

Kushnerev notices in his work that the main trial participants shall have a liability to observe the principle of legal proceedings in a reasonable term and not only the law $[8, \mathrm{p}$. 149].

The terms in criminal proceedings are the criterion of the efficient activity of the investigator, as when observing the specified term, the issue of sufficiency of its actions will be solved. In the opinion of Obraztsov [9], in case the investigator does not act efficiently within the framework of criminal proceedings, the interested parties can raise the question of the compliance of the reasonable term to the head of the investigating body.

Nikolyuk explains that to make the declaration norms included in the law of code of criminal procedure and reflecting the ideals of Russian criminal proceedings work, additional regulation is required. Otherwise, the declaration norms that are not based on the system of the more frequent norms playing the role of the guarantees of their proper application will become a "normative spam". The typical example in this regard is a story with the addition of the law of the reasonable term [10].

The original of Article 6.1 of the Russian Federation Code of Criminal Procedure [11] as it was reasonably mentioned by the scientists-processualists was not able to change the situation with the too long investigation and settlement of criminal cases, the serious changes of the whole system of criminal processing are required [12, p. 5].

However, until now the law-maker has not made any amendments regarding the terms in criminal proceedings. In foreign judicial literature, it is mentioned that in criminal proceedings the term under consideration starts from the date of filing an accusation to a person [1].

The latest position of the Constitutional Court of the Russian Federation specifies that the aggrieved party cannot be deprived of the right to file a claim for compensation if he or she has not received the formal status of the victim. These are the cases when the bodies did not initiate criminal proceedings in time and later refused to do it due to the expiration of the term of limitation. The Constitutional Court of the Russian Federation specifies that if the law-enforcement officials will delay the initiation of criminal proceedings and interrupt unreasonably the inspections following the crime incident report, this will mean the victims are deprived of their right of access to courts with a claim for compensation. The reasonable term of criminal proceedings starts from the date of criminal prosecution or the date of the crime incident report.

The conclusion made by Kovalenko is of interest; it says that for efficient and on-the-spot pretrial investigation, it is not enough to observe strictly the requirements of the procedural law by the authorized officials, to collect sufficient evidence, and build an efficient line of criminal prosecution in regard to the person who committed a crime. The general efficiency of pre-trial investigation requires the professionalism of the investigator [13], which, unfortunately, does not always exist in practice.

Thus, the analysis of the materials of case law confirms that in the majority of cases, the accrual of the right of production before the court for citizens is related to the improper fulfillment of the official duties of the bodies of preliminary investigation and court. For example, in his petition, J. specified that the actions of the preliminary investigation bodies for the timely investigation of the case were not efficient and administrative. Being in custody, the accused cannot prevent the carrying out of investigative activities as the 
participation of such accused in the procedural actions can be provided by the prisoner transfer. The court satisfied a motion of $\mathrm{J}$. as the general duration of proceeding of this criminal case was more than 8 years, believing that in this case, the reasonable term of proceeding was breached [14].

Among the reasons for the long investigation of criminal cases, judges mention: default of appearance of witnesses or other trial participants, disease of the prisoner, performing of multiple expert examinations of complicated criminal cases, prisoners' transfer from the prison facilities as the remoted location of the pretrial detention facility from the building of the court can be significant. Thus, in the practice of the author, there was a case when the criminal case was suspended due to the detection of the prisoner that took about three years, and later it was found out that the wanted person was convicted and served the sentence for other judgment in the prison Matrosskaya Tishina. While the person was wanted by the authorities, there were no messages to the court from the detectives. Thus the criminal case was investigated for about 4 years in total.

Another interesting fact from the practice can be the case when the prisoner himself is interested in a long investigation of his case (due to his satisfaction with the regime of the pretrial detention facility, he does not want to serve the sentence in the maximum-security prison). For example, in his last plea, prisoner Z. declared that he had not committed this crime and pointed at witness A. The latter did a forced military service and could not be interviewed in court. Thus to find out this witness and interview him, the court delayed the court sessions for two years until the witness finished his service. All this time, the period of detention of the prisoner was prolonged and he was kept at the pretrial detention facility.

Among the reasons for the delay of the proceeding of a criminal case, one should mention the following: duration of expert examinations, improper execution of decisions of compulsory attendance, default at the trial of lawyers without a good reason, etc. Besides, the authors believe that when estimating the behavior of the prisoner, the judge should not allow a formal attitude towards his or her actions in the court session as it can cause a breach of his or her right of defense. If the judge still believes such behavior of the prisoner shows the delay of the lawsuit such conclusion shall be confirmed by the evidence of the use of illegal means by the prisoner to protect his or her rights.

\section{Conclusion}

The system analysis of the scientific works and case law concerning the problem under consideration led the authors to the conclusion that the concept of terms in criminal proceedings should take place, but should this term be "reasonable" or "objective"? The authors believe the "reasonableness" (or the correspondence to common sense, justness) presupposes the availability of certain circumstances that take place in the particular actions of the people involved in the proceedings in a criminal case. Therefore, the objective term allows imagining the activity of the parties to the criminal process from the position of common sense and finally talking about the reasonable character of the maturity term.

The terms are legislated in the certain norms of the code of criminal procedure, in the actions of officials and state authorities, in particular, in the style of work of the investigator or detective; in the actions of other people involved in criminal proceedings (accused people, criminal defendants, lawyers).

Therefore, the authors suppose that the term should be objective (that is, unprejudiced, free from prejudice and subjective attitude) and depend upon the simplicity or complexity of the investigative activities and judicial proceedings. For one criminal case (simple theft), it can be 10 days but for another criminal case (serial murders) it can be more than 2 months. From the authors' point of view, the term "reasonable" is not right despite it already came into common use of law enforcers and most authors do not mind using it. Therefore, there is 
no need to make changes in the code of criminal procedure and Article 6.1 of the Russian Federation Code of Criminal Procedure in which the "reasonable" term is determined only as a principle of criminal proceedings and it should be kept at this stage.

However, it is reasonable to make corresponding changes to Article 5 of the Russian Federation Code of Criminal Procedure and legislate the concept of a reasonable term as a period of time when legal proceedings have an objective character without significant excess of the established terms of criminal proceedings.

The authors believe that the reasonable term can be associated possibly not only with the delay of criminal proceedings but also with their conduct in shorter terms than those established by the code of criminal procedure.

Thus, the reasonable term of criminal proceedings is a period of time when legal proceedings are performed before the expiration of the term established by the code of criminal procedure; or when legal proceedings are executed with the insignificant excess of the term established by the law of code of criminal procedure or prolonged in accordance with the established procedure.

\section{References}

1. R.V. del Carmen, Criminal procedure: law and practice (Cengage Learning, 2013)

2. R.K. Merton, J. Legal Pol. Sociol. 115 (1942)

3. J.B. Jacobs, K. Potter, Hate crimes: Criminal law and identity politics (Oxford University Press, New York, 2000)

4. P. Leach, Taking a case to the European Court of Human Rights (Oxford University Press, New York, 2017)

5. M.A. Eissen, The length of civil and criminal proceedings in the case-law of the European Court of Human Rights (Council of Europe Publishing, Strasbourg, 1996)

6. V.M. Bykov, Zakonnost, 11, 23 (2010)

7. A.A. Barygina, Russian Justice, 4, 43-46 (2015)

8. V.I. Kushnerev, Proceedings of Management Academy of the Ministry of the Interior of Russia, 2(42), 147-150 (2017)

9. A.V. Obraztsov, Russian Investigator, 23, 30-33 (2016)

10. V.V. Nikolyuk, Scientific Bulletin of the Omsk Academy of the Ministry of Internal Affairs of Russia, 2(77), 19-25 (2020)

11. Collection of Legislation of the Russian Federation, 52 (part I), Item 492 (2001)

12. V.A. Azarov, D.G. Rozhkov, Obespechenie razumnogo sroka ugolovnogo sudoproizvodstva $\mathrm{v}$ sude pervoi instantsii [Provision of a reasonable term of criminal proceedings in a trial court] (Publishing House of Omsk State University Omsk, Omsk, 2013)

13. A.V. Kovalenko, Forensic recommendations for the pre-trial investigation as a means of ensuring the access to a fair trial in criminal proceedings, in International Scientific and Practical Conference "Legal Science, Legislation and Law Enforcement Practice: Regularities and Development Trends", October 30-31, 2020, Lublin, 353-355 (Baltija Publishing, Riga, 2020). https://doi.org/10.30525/978-9934-588-92-1-88

14. Reshenie No. 3A-213/2018 3A-32/2019 3A-32/2019(3A-213/2018;) M-387/2018 M$387 / 2018$ ot 14 fevralya 2019 g. po delu No. 3A-213/2018 [Decision No. 3A-213/2018 3A-32/2019 3A-32/2019(3A-213/2018;) M-387/2018 M-387/2018 in case N3A- 
213/2018] (2019, February 14). Accessed on: November 25, 2020. [Online]. Available: https://sudact.ru/regular/doc/wY3UNqqo36xB/ 